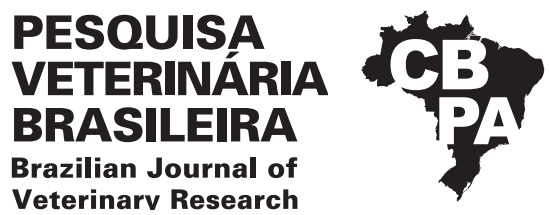

Pesq. Vet. Bras. 41:e06719, 2021

DOI: 10.1590/1678-5150-PVB-6719

Original Article

ISSN 0100-736X (Print)

Wildlife Medicine

ISSN 1678-5150 (Online)

\title{
Bovine tuberculosis in safari park in Brazil ${ }^{1}$
}

\author{
Daiane A.R. Lima² (D), Rudielle A. Rodrigues ${ }^{2}$, Rodrigo N. Etges ${ }^{3}$ (D) \\ and Flábio R. Araújo ${ }^{4 *}$ (i)
}

\begin{abstract}
Lima D.A.R., Rodrigues R.A., Etges R.N. \& Araújo F.R 2021. Bovine tuberculosis in safari park in Brazil. Pesquisa Veterinária Brasileira 41:e06719, 2021. Embrapa Gado de Corte, Av. Rádio Maia 830, Campo Grande, MS 79106-550, Brazil. E-mail: flabio.araujo@embrapa.br

Bovine tuberculosis (bTB) is an infectious disease caused by Mycobacterium bovis, affecting domestic animals, wild animals and humans. In captivity, for wild animals, bTB represents a risk to animal keepers and zoo visitors, in addition to the possibility of spreading the infection to domestic animals or through the trade of infected wild animals. Sambar (Cervus unicolor), red deer (Cervus elaphus) and fallow deer (Dama dama) from a safari park in the State of Rio Grande do Sul, Brazil, showed a clinical condition of dyspnea and weight loss. Some animals died and showed lesions suggestive of tuberculosis (LST), which were confirmed by histopathology. After the interdiction of the safari park by the state veterinary authorities, 281 deer were euthanized with the authorization of the "Instituto Brasileiro do Meio Ambiente e dos Recursos Naturais Renováveis" (IBAMA). Retropharyngeal and submandibular lymph nodes and viscera were collected from 21 animals, which were grown in Stonebrink medium for up to 90 days. After DNA extraction from the bacterial colonies, PCR was performed for targets flanking the region of differentiation 4 (RD4). Of the 21 samples, 14 (66.7\%) presented LST with a granulomatous appearance, a whitish coloration, and caseous or calcified consistency, and seven samples (33.3\%), showed no lesions. In the culture of 14 samples with LST, 13 (92.8\%) presented bacterial growth compatible with $M$. bovis. In the cultivation of the seven samples without LST, four (57.1\%) presented colonies compatible with $M$. bovis. PCR and DNA sequencing of the PCR amplicons detected as positive all the 17 $(100 \%)$ bacteriological cultures suggestive of $M$. bovis, thus confirming the outbreak of bTB in deer. Decisions about positive tested and suspicious animals should be taken based on the evaluation of the risk of transmission to the rest of the zoological animals, animal welfare, conservation considerations and, the zoonotic potential of this pathogen.
\end{abstract}

INDEX TERMS: Bovine tuberculosis, Brazil, Mycobacterium bovis, zoonosis, PCR, deer, wildlife animals.

RESUMO.- [Tuberculose bovina em parque safári no Brasil.] A tuberculose bovina (bTB) é uma doença infecciosa causada por Mycobacterium bovis, afetando animais domésticos, animais selvagens e humanos. Para animais selvagens em cativeiro, a bTB representa um risco para os tratadores de animais e visitantes do zoológico, além da possibilidade de espalhar a

\footnotetext{
${ }^{1}$ Received on July 6, 2020.

Accepted for publication on September 4, 2020

${ }^{2}$ Graduate Program in Veterinary Sciences, Faculdade de Medicina Veterinária e Zootecnia (FAMEZ), Universidade Federal de Mato Grosso do Sul (UFMS), Av. Senador Filinto Muller 2443, Cidade Universitária, Campo Grande, MS 79070-900, Brazil.

${ }^{3}$ Secretaria da Agricultura, Pecuária e Irrigação, Av. Getúlio Vargas 1384, Menino Deus, Porto Alegre, RS 90150-004, Brazil.

${ }^{4}$ Laboratório de Imunologia, Sanidade Animal, Embrapa Gado de Corte, Av. Rádio Maia 830, Zona Rural, Campo Grande, MS 70106-550, Brazil. *Corresponding author: flabio.araujo@embrapa.br
}

infecção para animais domésticos ou por meio do comércio de animais silvestres infectados. Cervídeos sambar (Cervus unicolor), veado-vermelho (Cervus elaphus) e gamo (Dama dama) de um parque safári no Estado do Rio Grande do Sul, Brasil, mostraram uma condição clínica de dispneia e perda de peso. Alguns animais morreram e apresentaram lesões sugestivas de tuberculose (LST), as quais foram confirmadas por histopatologia. Após a interdição do parque safári pelas autoridades veterinárias estaduais, 281 veados sofreram eutanásia com a autorização do Instituto Brasileiro do Meio Ambiente e dos Recursos Naturais Renováveis (IBAMA). Os linfonodos retrofaríngeos e submandibulares e vísceras foram coletados de 21 animais, que foram cultivados em meio Stonebrink por até 90 dias. Após extração de DNA das colônias bacterianas, foi realizada PCR para alvos que flanqueavam a região de diferenciação 4 (RD4). Das 21 amostras, 14 (66,7\%) apresentaram LST com aspecto granulomatoso, coloração 
esbranquiçada e consistência caseosa ou calcificada, e sete amostras $(33,3 \%)$ não apresentaram lesões. Na cultura de 14 amostras com LST, $13(92,8 \%)$ apresentaram crescimento bacteriano compatível com $M$. bovis. No cultivo das sete amostras sem LST, quatro $(57,1 \%)$ apresentaram colônias compatíveis com M. bovis. A PCR e o sequenciamento de DNA dos fragmentos de PCR detectaram como positivo todas as $17(100 \%)$ culturas bacteriológicas sugestivas de M. bovis, confirmando assim o surto de bTB em cervídeos. As decisões sobre animais positivos testados e suspeitos devem ser tomadas com base na avaliação do risco de transmissão para o restante dos animais zoológicos, bem-estar animal, considerações de conservação e no potencial zoonótico desse patógeno.

TERMOS PARA INDEXAÇÃO: Tuberculose bovina, Brasil, Mycobacterium bovis, zoonose, PCR, cervídeos, animais selvagens.

\section{INTRODUCTION}

Bovine tuberculosis (bTB) is a chronic and debilitating disease, caused by Mycobacterium bovis, a bacterium belonging to the Mycobacterium tuberculosis (MTC) complex (Mol et al. 2016). The main host of $M$. bovis is bovine, but it also affects a wide variety of other domestic and wild species, including humans (Kohl et al. 2018).

The occurrence of infection by Mycobacterium sp. in wild animals kept in captivity has been widely described. At the Audubon Zoo, New Orleans, there was an outbreak of bTB, which caused the death of four white rhinos (Ceratotherium simum) and two white colobus monkeys (Colobus guereza caudatus). An outbreak of bTB resulted in the infection of a Mayotte lemur (Lemur mayottensis mayottensis), a lion-tailed macaque (Macacus silenus), a foot monkey (Erythrocebus patas) and a siamang (Symphalangus syndactylus) at Dublin Zoo (Rocha et al. 2011).

In Brazil, at Zoo Safari, which is part of the São Paulo Zoological Foundation, State of São Paulo, a pair of pivas (Kobus ellipsiprymnus) showed symptoms of bTB; the diagnosis being confirmed by necropsy (Rocha et al. 2011).

Species such as elk (Cervus canadensis), white-tailed deer (Odocoileus virginianus), sika deer (Cervus nippon), caribou (Rangifer tarandus), eared deer (Odocoileus hemionus), fallow deer (Dama-dama) and moose (Alces alces) are naturally infected by M. bovis, a fact that harms bTB eradication programs in developed countries (Miller 2008).

Due to its zoonotic character, an infection by $M$. bovis in wild animals kept in captivity represents a risk for animal keepers and visitors to parks and zoos. It also demonstrates the indispensability of a rapid and accurate diagnosis in wild animals (Ribeiro et al. 2017).

In the farming of wild animals, in addition to the risks already mentioned, it is also possible to spread the infection to domestic animals in surrounding farms. The trade of infected wild animals can also spread the infection to other areas (Ribeiro et al. 2017, Zimpel et al. 2017a).

Symptoms of bTB are hardly noticeable before death in zoos, since most infected animals are asymptomatic until an acute stage of infection. However, some clinical signs can be noticed, such as weakness, chronic weight loss, dyspnea, coughs and lymph node enlargement (Lécu \& Ball 2011).

The signs of coughs and dyspnea usually indicate the final and irreversible course of the pulmonary form of bTB.
Chronic weight loss, on the other hand, is the most observed sign among wild mammals (Ferreira Neto et al. 2014).

This study describes an outbreak of bTB in deer at a safari park in the State of Rio Grande do Sul, Brazil.

\section{MATERIALS AND METHODS}

Sampling. The study was carried out using 21 tissue samples of deer, of the species sambar (Cervus unicolor), red deer (Cervus elaphus) and fallow deer (Dama dama), from a safari park, located in the state of Rio Grande do Sul, Brazil. In this park, there was a prior notification of bovine and buffalo tuberculosis in eight animals, which were euthanized according to the National Program for the Control and Eradication of Brucellosis and Animal Tuberculosis (PNCEBT). Posteriorly, Mycobacterium bovis was detected by PCR in the blood of 28/86 (32.6\%) deer from the safari park, and the infected animals were euthanized and necropsied. Caseous and calcified lesions, suggestive of bTB (LST), were identified.

As the PNCEBT does not describe the intradermal test methodology for cervids, the procedure adopted by the United States Department of Agriculture (USDA) was used. This procedure was performed after a total neck trichotomy, and intradermal injection of purified protein derived (PPD) of M. bovis and PPD of Mycobacterium avium $(0.1 \mathrm{~mL}$ each), as recommended by the technique (USDA 2005). Among the 55 animals, 16 (29.1\%) were positive in the intradermal test.

The owners of the park had the intention of selling all the deer to other parks and farms in Brazil. Nevertheless, a court order forced them to choose between restricting sales to only CCT negative animals, according to the official veterinary service, or depopulation of the entire deer herd.

The state veterinary authorities issued notification of interdiction to the safari park, and all the remaining 281 deer were euthanized.

During slaughter, retropharyngeal, submandibular and viscera lymph nodes were collected randomly from 21 animals, with or without lesions suggestive of tuberculosis (LST). The tissue samples were packed separately in sealed plastic bags. Then, they were immediately placed in screw cap bottles, and the samples were frozen for later shipment, under refrigeration, in a thermal insulating box, which was inserted in a cardboard box, indicating that it was an infectious material, complying with the standards determined by Packaging Instruction P650-IATA (International Air Transport Association). The samples were then sent to the Laboratory of Animal Immunology of Embrapa Beef Cattle, Campo Grande/MS, for confirmation by culture and PCR/DNA sequencing.

Isolation of Mycobacterium bovis. The tissue samples were kept frozen at $-30^{\circ} \mathrm{C}$ until processed. The fragments corresponding to the transition between gross lesions and apparently healthy areas of the samples (between 10 and $25 \mathrm{mg}$ ) were macerated with $1.5 \mathrm{~mL}$ of sterile distilled water in a Magna Lyser device (Roche Life Science), using ceramic spheres (MagNA Lyser Green Beads), for 30 seconds, at 6,000rpm, three times.

The aqueous phase resulting from the maceration was subjected to decontamination by the Petroff method (Makovcova et al. 2015) and grown in Stonebrink culture medium, incubated at $37^{\circ} \mathrm{C}$ and evaluated weekly for up to 90 days.

DNA extraction for identification of Mycobacterium bovis. After the growth of colonies suggestive of $M$. bovis, they were collected with an inoculation loop, resuspending the bacterial mass in an Eppendorf tube containing $200 \mu \mathrm{L}$ of tris-EDTA, followed by inactivation by heating in a thermoblock at $85^{\circ} \mathrm{C}$ for 30 minutes. Then, it was centrifuged at $13,000 \times g$ for two minutes. The precipitate 
formed was discarded and the supernatant with mycobacterial DNA was transferred to new tubes and stored at $-20^{\circ} \mathrm{C}$ for further analysis.

PCR identification. The DNAs extracted from the colonies were submitted to conventional Mb.400 PCR according to the protocol of Sales et al. (2014), which consists of the amplification of a DNA fragment of 400 base pairs (bp) and that flanks the region of differentiation 4 (Region of Difference 4 - RD4), specific to M. bovis. The primers used were: Mb.400.F (5'AACGCGACGACCTCATATTC3') and Mb.400.R (5'AAGGCGAACAGATTCAGCAT3').

Conventional PCR was performed in an MJ mini/personal thermal cycler (Bio-rad). The reactions were carried out in a final volume of $25 \mu \mathrm{L}$, containing $2.5 \mu \mathrm{L}$ of $10 x$ PCR buffer $\left(\mathrm{MgCl}_{2}\right) ; 1.5 \mathrm{mM} \mathrm{MgCl}_{2} ; 0.5 \mu \mathrm{L}$ of each primer (20pmol); $0.25 \mathrm{U}$ of Taq DNA polymerase (Invitrogen); $0.5 \mu \mathrm{L}$ of dNTP mix [(10mM deoxynucleoside triphosphate (Invitrogen)]; $3 \mu \mathrm{L}$ of DNA. The amplification consisted of initial denaturation at $95^{\circ} \mathrm{C}$ for 5 minutes, followed by 35 cycles of denaturation at $95^{\circ} \mathrm{C}$ (30 seconds), annealing at $56^{\circ} \mathrm{C}\left(30\right.$ seconds) and extension at $72^{\circ} \mathrm{C}$ ( 30 seconds), with a final extension step at $72^{\circ} \mathrm{C}$ for 5 minutes. The amplified PCR products were stained with Gel Red and subjected to electrophoresis in 1\% agarose gel with TAE $1 \mathrm{X}$ buffer and observed in a photo-documenter (Bio-Rad), under ultraviolet light.

DNA sequencing. The BigDye Terminator cycle sequencing kit (version 3.1, Applied Biosystems, Foster City/CA, USA), for sequencing DNA reactions, with a total volume reaction of $10 \mu \mathrm{L}$, with $1 \mu \mathrm{L}$ of DNA (50ng/ $\mu \mathrm{L}), 5.8 \mu \mathrm{L}$ ultrapure water type $1,2 \mu \mathrm{L}$ of $5 \mathrm{x}$ sequencing buffer, $0.5 \mu \mathrm{L}$ of $\mathrm{Mb} .400 \mathrm{R}(5 \mathrm{mM})$ primers and $0.7 \mu \mathrm{L}$ of the reaction compound ready for BigDye Terminator v3.1. In an MJ Mini thermal cycler (Biorad) operating in a program at $96^{\circ} \mathrm{C}$ for 1 minute, followed by 25 cycles of $96^{\circ} \mathrm{C}$ for 10 seconds, $50^{\circ} \mathrm{C}$ for 5 seconds and $60^{\circ} \mathrm{C}$ for 4 minutes, amplifications were followed. The purification step was carried out with EDTA (125mM, pH 8.0), $70 \%$ ethanol and $100 \%$ ethanol. The sequencing of the purified PCR products was carried out in an ABI-3130 automatic sequencer (Applied Biosystems, USA).

Local alignment of DNA sequences. Sequence Scanner Software was used to view and edit the data generated by the ABI-3130 genetic analyzer after it has been processed by Sequencing Analysis Software. The results of these DNA sequences were compared to the database $\mathrm{nr} / \mathrm{nt}$ by Blastn ${ }^{5}$.

\section{RESULTS}

Of the 21 tissue samples of deer analyzed, 14 (66.7\%) had STL, with granulomatous appearance, whitish color, and caseous or calcified consistency (Fig.1), while seven (33.3\%) did not present lesions. In the culture of the 14 samples that presented LST in Stonebrink medium, 13 (92.8\%) presented bacterial growth with morphology compatible with Mycobacterium bovis, that is, small, rounded colonies, yellow-cream color and with irregular edges. In the cultivation of the seven samples without LST, four (57.1\%) had colonies compatible with M. bovis.

Conventional PCR detected as positive all the 17 (100\%) bacteriological cultures suggestive of $M$. bovis, confirming the bTB outbreak in deer (Fig.2). The data obtained in this study demonstrated that the PCR technique was effective for the detection of $M$. bovis, resulting in the amplification of a 400 (bp) fragment that flanked the differentiation region 4 (RD4), absent in $M$. bovis, but existing in the other members of the

$\overline{5}$ Available at <https://blast.ncbi.nlm.nih. gov/Blast.cgi>
MTC. The sequencing of the RD4 DNA fragment resulting from the specific PCR of $M$. bovis was performed in 17 samples, resulting in DNA sequences with 99 to $100 \%$ identity to the homologous fragment in the isolate AF2122/97 from M. bovis (Sequence ID: LT708304).

\section{DISCUSSION}

The control of bTB in deer has been difficult due to the lack of an efficient diagnosis, due to the specificity and sensitivity of variables to the intradermal test, and also because of the difficulty in distinguishing infections by Mycobacterium bovis from those caused by Mycobacterium avium and other mycobacteria (Ribeiro et al. 2017, Zimpel et al. 2017a).

The clinical diagnosis is limited due to the late occurrence and non-specificity of the signs. Thus, the diagnosis in deer

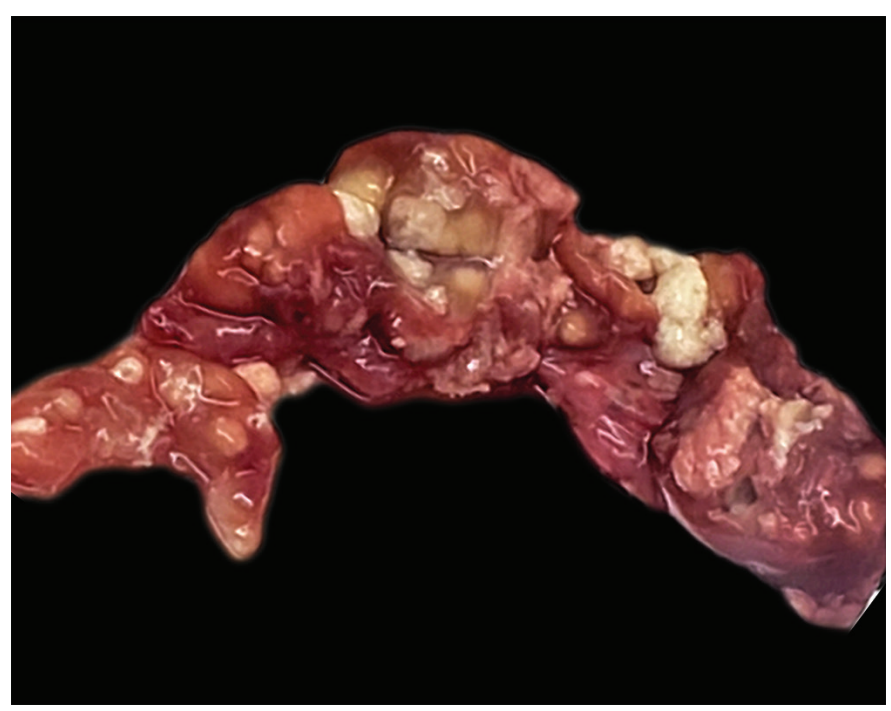

Fig.1. Lesion suggestive of bovine tuberculosis in a cervical lymph node.

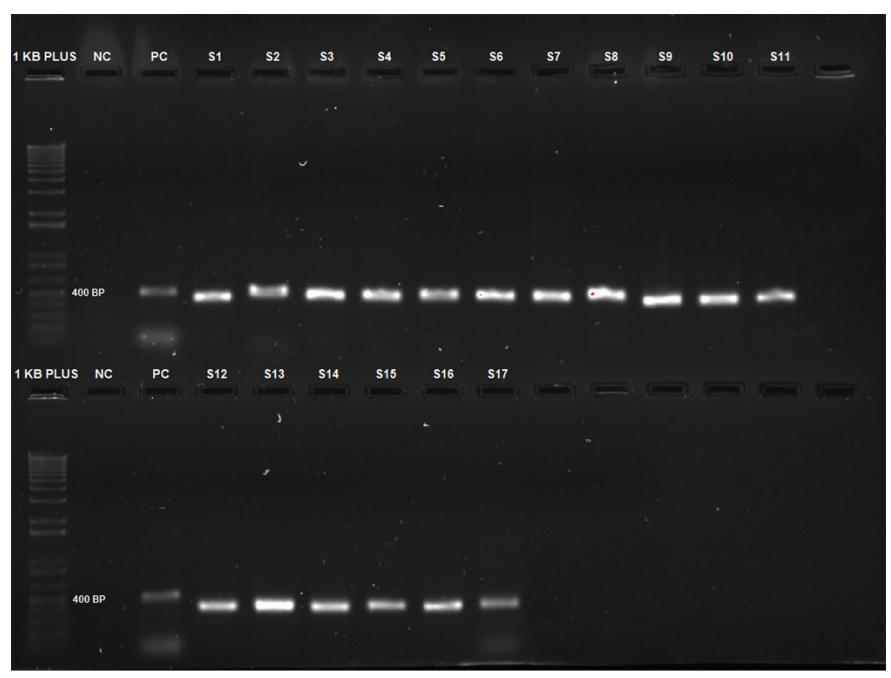

Fig.2. PCR amplification targeting the region of differentiation 4 of Mycobacterium bovis ( $\mathrm{NC}=$ negative control, $\mathrm{PC}=$ positive control, S1-17 = samples), in clinical samples of deer from the Rio Grande do Sul safari park. Molecular marker $1 \mathrm{~Kb}$ Plus DNA ladder (Invitrogen). 
is based on intradermal reaction tests, although they are not properly standardized for them (Ribeiro et al. 2017).

Miller (2008) suggests necropsy with the collection of all organs, preferably the lymph nodes, of all deer with natural death or who were euthanized. Thus, the diagnosis is often based on the identification of lesions.

According to Delahay et al. (2007), the presence of isolated lesions is not a confirmatory indicator of $M$. bovis infection in wild animals. In Germany, a protocol for bTB diagnosis was standardized based on skin tests with PPD (ante mortem), an interferon-gamma release assay (ante mortem), bacteriological culture (post mortem) and a highly specific examination, based on PCR in real time for the detection of MTC DNA in animal tissues (post mortem) (Fell et al. 2016).

Bacterial culture is considered the gold standard for establishing the diagnosis of tuberculosis and can be performed by inoculating $M$. bovis in solid culture media, with Stonebrink being the main medium used to isolate M. bovis, due to the difficulty of this species growing in glycerin media and developing in a medium containing sodium pyruvate (OIE 2018).

Although the definitive diagnosis of tuberculosis is based on isolation and identification, this technique presents some difficulties, such as low sensitivity, requiring a considerable number of viable bacilli and a prolonged time for them to grow (up to 90 days). These conditions are not always met, due to decontamination methods, which in addition to eliminating contaminants, can also compromise some bacilli chosen for isolation (Ruggiero et al. 2007). In addition, the definitive classification of the cultivated mycobacterium species is only feasible by biochemical and drug sensitivity tests, which require a long period and may show non-specificity (Fuverki et al. 2008).

The use of techniques and methods involving molecular biology, such as Polymerase Chain Reaction (PCR), has reduced the time required for the diagnosis of bTB. Several studies demonstrate the use of PCR in complementing the identification of $M$. bovis (Zumárraga et al. 2012, Barandiaran et al. 2019, Fico et al. 2019), such as the work of Elsayed \& Amer (2019), who used PCR directly from tissue samples, demonstrating the technique's speed compared to cultivation for species identification.

Sales et al. (2014) compared different primers for the detection of M. bovis, proving that Mb.400 primers, targeting fragments flanking the region of differentiation 4 (RD4), are the ones that demonstrated the best results in the PCR for bTB. The RD4 region, which includes the rv1506 - rv1516 genes, is deleted in the genome of $M$. bovis and M. bovis BCG, although it is present in the genome of other members of the MTC (Brosch et al. 2002).

The MTC is a class of microorganisms with great genetic similarity. The M. bovis genome is $99.95 \%$ similar to Mycobacterium tuberculosis; DNA deletions are a major contributor to these differences. Thus, the importance of identifying the species of MTC isolates for epidemiological studies and public health (Zimpel et al. 2017b).

Tuberculosis in zoo species, or those living free in national parks, constitutes the majority of reported cases of the disease in the literature. In Curitiba Zoo, located in the south of the State of Paraná, Brazil, the case of a 13-year-old bison (Bison bonasus), born in captivity, who presented weight loss, diarrhea, cough and purulent nasal discharge was described after death (Zimpel et al. 2017a).

At the necropsy of the animal, there was an increase in lymph nodes, areas of multifocal consolidation in the pulmonary lobes; these nodes being mostly firm and pale yellow in appearance, with a central caseous mass containing firm white material consistent with mineralization. As there were already reports of tuberculosis in other species in this same zoo, they proceeded with a bacteriological culture and the use of the PCR technique, to confirm the presence of $M$. bovis (Zimpel et al. 2017a).

Infected animals, captive or free, can spread the disease to other species kept in captivity or in nearby regions, such as farms and other livestock (Barasona et al. 2016, Zimpel et al. 2017a), as well as to humans in proximity to these animals (De la Rua-Domenech 2006), thus causing interspecies transmission.

The transmission of bTB from wild animals to keepers is also a concern. Alpacas infected with $M$. bovis were a source of infection for a handler, who presented a clinical picture similar to a severe flu. Chest radiography revealed a suspicion of pulmonary tuberculosis, confirmed after a sputum culture (Barkham 2012).

Bovine tuberculosis remains a disease of great importance in cattle and humans. However, as discussed throughout the present study, wild animals can be a potential source of infection and one of the causes for the ineffectiveness of eradicating the disease (Di Marco et al. 2012). Therefore, it is of paramount importance, both for animal health and public health, to carry out the diagnosis of bTB in these species and, from there, restrict animal transit and ensure the euthanasia of infected animals, when necessary. Decisions on positive, and suspicious, animals should be taken based on the evaluation of the risk of transmission to the rest of the zoological animals, animal welfare, conservation considerations and, the zoonotic potential of this pathogen (Lécu \& Ball 2011).

It was not possible, in this study, to verify the origin of bTB detected in cervids. Therefore, studies of genome sequencing of the isolates of deer and cattle, from the same region, are necessary to investigate whether the transmission occurred from infected cattle, or another source.

\section{CONCLUSION}

An outbreak of bovine tuberculosis was confirmed in captive deer in the State of Rio Grande do Sul, with the presence of lesions suggestive of the disease and confirmed by culture and PCR/DNA sequencing.

Acknowledgements.- To "Fundação de Apoio ao Desenvolvimento do Ensino, Ciência e Tecnologia do Estado de Mato Grosso do Sul" (Fundect), Brazil, process 59/300.121/2015 and project 085/2015; and "Conselho Nacional de Desenvolvimento Científico e Tecnológico" (CNPq), Brazil, process 407826/2018-1.

Conflict of interest statement.- The authors have no competing interests.

\section{REFERENCES}

Barandiaran S., Pérez Aguirreburualde M.S., Marfil M.J., Martínez Vivot M., Aznar N., Zumárraga M. \& Perez A.M. 2019. Bayesian assessment of the accuracy of a PCR-Based rapid diagnostic test for bovine tuberculosis in swine. Front. Vet. Sci. 6:204. <https://dx.doi.org/10.3389/fvets.2019.00204> <PMid:31297374> 
Barasona J.A., Vicente J., Díez-Delgado I., Aznar J., Gortázar C. \& Torres M.J. 2016. Environmental presence of Mycobacterium tuberculosis complex in aggregation points at the wildlife/livestock interface. Transbound. Emerg. Dis. 64(4):11481158. <https://dx.doi.org/10.1111/tbed.12480> <PMid:26865411>

Barkham P. 2012. Fears alpacas could spread bovine TB. The Guardian. Available at <https://www.theguardian.com/environment/2012/may/14/ fears-alpacas-spread-bovine-tb> Accessed on Oct., 2019.

Brosch R., Gordon S.V., Marmiesse M., Brodin P., Buchrieser C., Eiglmeier K., Garnier T., Gutierrez C., Hewinson G., Kremer K., Parsons L.M., Pym A.S., Samper S., Van Soolingen D. \& Cole S.T. 2002. A new evolutionary scenario for the Mycobacterium Tuberculosis complex. Proceedings National Academy of Sciences of the United States America 99(06):3684-3689. <https://dx.doi.org/10.1073/pnas.052548299> <PMid:11891304>

De la Rua-Domenech R. 2006. Human Mycobacterium bovis infection in the United Kingdom: incidence, risks, control measures and review of the zoonotic aspects of bovine tuberculosis. Tuberculosis, Edinburgh, 86(2):77-109. <https://dx.doi.org/10.1016/j.tube.2005.05.002 > <PMid:16257579>

Delahay R.J., Smith G.C., Barlow A.M., Harris A., Clifton-Hadley R.S \& Cheeseman C.L. 2007. Bovine tuberculosis infection in wild mammals in the South-West region of England: a survey of prevalence and a semiquantitative assessment of the relative risks to cattle. Vet. J. 173(2):287-301. <https://dx.doi.org/10.1016/j.tvjl.2005.11.011> <PMid:16434219>

Di Marco V., Mazzone P., Capucchio M.T., Boniotti M.B., Aronica V., Russo M., Fiasconaro M., Cifani N., Corneli S., Biasibetti E., Biagetti M., Pacciarini M.L., Cagiola M., Pasquali P. \& Marianelli C. 2012. Epidemiological significance of the domestic black pig (Sus scrofa) in Maintenance of bovine tuberculosis in Sicily. J. Clin. Microbiol. 50(4):1209-1218. <https://dx.doi.org/10.1128/ JCM.06544-11><PMid:22322347>

Elsayed M.S.A.E. \& Amer A. 2019. The rapid detection and differentiation of Mycobacterium tuberculosis complex members from cattle and water buffaloes in the delta area of Egypt, using a combination of real-time and conventional PCR. Molecular Biol. Reports 46(4):3909-3919. <https://dx.doi.org/10.1007/s11033-019-04834-3><PMid:31041672>

Fell S., Bröckl S., Büttner M., Rettinger A., Zimmermann P. \& Straubinger R.K. 2016. Two alternative DNA extraction methods to improve the detection of Mycobacterium-tuberculosis-complex members in cattle and red deer tissue samples. BMC Microbiol. 16:213. <https://dx.doi.org/10.1186/ s12866-016-0816-2><PMid:27629399>

Ferreira Neto J.S., Valvassoura T. \& Catão-Dias J.L. 2014. Avanços no diagnóstico da tuberculose em animais selvagens, p.1382-1388. In: Cubas Z.S., Silva J.C.R. \& Catão-Dias J.L. (Eds), Tratado de Animais Selvagens. 2ª ed. Roca, São Paulo.

Fico R., Mariacher A., Franco A., Ciarrocca E., Pacciarini M.L. \& Battisti A. 2019 Systemic tuberculosis by Mycobacterium bovis in a free-ranging marsican brown bear (Ursus arctos marsicanus): a case report. BMC Vet. Res. 15(1):152. <https://dx.doi.org/10.1186/s12917-019-1910-0> <PMid:31101105>

Fuverki R.B.N., Murakami P.S., Biondo A.W. \& Barros Filho I.R. 2008. Uso da PCR para detecção e identificação de micobacterias a partir de amostras clínicas de bovinos. Arch. Vet. Sci. 13(1):73-77.<https://dx.doi.org/10.5380/ avs.v13i1.11562>

Kohl T.A., Utpatel C., Niemann S. \& Moser I. 2018. Mycobacterium bovis persistence in two different captive wild animal populations in Germany: a longitudinal molecular epidemiological study revealing pathogen transmission by whole-genome sequencing. J. Clin. Microbiol. 56(9):e00302-18. <https://dx.doi.org/10.1128/JCM.00302-18> <PMid:29950330>

Lécu A. \& Ball R. 2011. Mycobacterial infections in zoo animals: relevance, diagnosis and management. Int. Zoo Yearbook 45(1):183-202. <https:// dx.doi.org/10.1111/j.1748-1090.2011.00141.x>
Makovcova J., Babak V., Slany M. \& Slana I. 2015. Comparison of methods for the isolation of mycobacteria from water treatment plant sludge. Antonie Van Leeuwenhoek 107(5):1165-1179. <https://dx.doi.org/10.1007/ s10482-015-0408-4><PMid:25724128>

Miller R.E. 2008. Current diagnostic methods for tuberculosis in zoo animals, p.10-19. In: Miller R.E. \& Murray E.F. (Eds), Zoo and Wild Animal Medicine 6a ed. Saunders/Elsevier: St Louis, MO. <https://dx.doi.org/10.1016/ B978-141604047-7.50005-1>

Mol J.P.S., Carvalho T.F., Fonseca Jr A.A., Sales E.B., Issa M.A., Rezende L.C., Hodon M.A., Tinoco H.P., Malta M.C.C., Pessanha A.T., Pierezan F., Mota P.M.P.C., Paixão T.A. \& Santos R.L. 2016. Tuberculosis caused by mycobacterium bovis in a capybara (Hydrochoerus hydrochaeris). J. Comp. Pathol. 155(2/3):254258. <https://dx.doi.org/10.1016/j.jcpa.2016.05.014><PMid:27363904>

OIE 2018. Bovine Tuberculosis: manual of diagnostic test and vaccines for terrestrial animals 2019. Chapter 3.4.6, World Organization for Animal Health, p.1-17. Available at <https://www.oie.int/fileadmin/Home/eng/ Health_standards/tahm/3.04.06_BOVINE_TB.pdf> Accessed on Oct. 19, 2019.

Ribeiro V.L., Souza S.O., Casagrande R.A., Wouters A.T.B., Wouters F., Rolim V.M., Santos E.O. \& Driemeier D. 2017. Infecção por Mycobacterium sp. em herbívoros selvagens de cativeiro no Rio Grande do Sul: estudo retrospectivo e detecção imuno-histoquímica (2003-2015). Pesq. Vet. Bras. 37(1):58-65. <https://dx.doi.org/10.1590/s0100-736x2017000100010>

Rocha V.C.M., Corrêa S.H.R., Oliveira E.M.D., Rodriguez C.A.R., Fedullo J.D., Maltrone M., Setzer A., Yuka C.Y., Verajano M.P., Figueiredo S.M. \& Ferreira Neto J.S. 2011. Tuberculosis determined by Mycobacterium bovis in captive waterbucks (Kobus ellipsiprymnus) in São Paulo, Brazil. Braz. J. Microbiol 42(2):726-728. <https://dx.doi.org/10.1590/S1517-83822011000200040>

Ruggiero A.P., Ikuno A.A., Ferreira V.C.A. \& Roxo E. 2007. Artigo de revisão tuberculose bovina: alternativas para o diagnóstico. Arq. Inst. Biológico, São Paulo, 74(1):55-65.

Sales M.L., Fonseca A.A., Sales É.B., Cottorelo A.C.P., Issa M.A., Hodon M.A., Filho P.M.S., Ramallho A.K., Silva M.R., Lage A.P. \& Heinemann M.B. 2014. Evaluation of molecular markers for the diagnosis of Mycobacterium bovis. Folia Microbiol. 59(5):433-438. <https://dx.doi.org/10.1007/s12223014-0317-3><PMid:24744007>

USDA 2005. Uniform Methods and Rules. Bovine Tuberculosis Eradication, Animal and Plant Health Inspection Service, United States Department of Agriculture, USA. 35p.

Zimpel C.K., Brandão P.E., Filho A.F.S., Souza R.F., Ikuta C.Y., Ferreira Neto J.S., Camargo N.C.S., Heinemann M.B. \& Guimarães A.M.S. 2017b. Complete genome sequencing of Mycobacterium bovis SP38 and comparative genomics of Mycobacterium bovis and M. tuberculosis strains. Front. Microbiol. 8:2389. <https://dx.doi.org/10.3389/fmicb.2017.02389> <PMid:29259589>

Zimpel C.K., Brum J.S., De Souza Filho A.F., Biondo A.W., Perotta J.H., Dib C.C. \& Guimaraes A.M. 2017a. Mycobacterium bovis in a European bison (Bison bonasus) raises concerns about tuberculosis in Brazilian captive wildlife populations: a case report. BMC Res. Notes 10(1)91. <https://dx.doi. org/10.1186/s13104-017-2413-3><PMid:28187776>

Zumárraga M.J., Arriaga C., Barandiaran S., Cobos-Marín L., De Waarde J., Estrada-Garcia I., Figueiredo T., Figueroa A., Giméneze F., Gomes H.M., Gonzalez-Y-Merchand J.A., Macías A., Milián-Suazo F., Rodríguez C.A.R., Santillán M.A., Suffys P.N., Trangoni M.D., Zárragaha M.A. \& Cataldi A. 2012. Understanding the relationship between Mycobacterium bovis spoligotypes from cattle in Latin American Countries. Res. Vet. Sci. 94(1):9-21.<https:// dx.doi.org/10.1016/j.rvsc.2012.07.012><PMid:22884173> 